\title{
COMMENTARY
}

\section{“Treat everybody right": Examining foodways to improve food access}

\author{
Alex B. Hill * \\ Wayne State University
}

Submitted April 30, 2020 / Revised October 22, 2020, and February 3, 2021 / Published online May 26, 2021

Citation: Hill, A B. (2021). "Treat everybody right": Examining foodways to improve food access. Journal of

Agriculture, Food Systems, and Community Development, 10(3), 9-16. https://doi.org/10.5304/jafscd.2021.103.012

Copyright (C) 2021 by the Author. Published by the Lyson Center for Civic Agriculture and Food Systems. Open access under CC-BY license.

\begin{abstract}
Detroit is regularly assumed to be a "food desert" despite contradicting evidence. With fruits and vegetables available at each of Detroit's 70 independent, full-line grocery stores, there remains a lack of understanding among media and academics of residents' perception and preferences for food access. A baseline study was initiated during the summer of 2014 to understand residents' own perceptions of food access and to assess the socio-cultural foodways utilized by residents. A total of 207 Detroit residents participated in focus groups and interviews to discuss food provisioning. Residents identified a wide range of food access points, from home gardens and fishing to specialty meat markets and big-box stores. However, $60 \%$ of residents reported that their primary grocery store was a chain supermarket outside the city limits. Residents highlighted "customer service" and in-store treatment as key factors in choosing where to shop for food. These new findings present contradictions to assumptions about food access in Detroit and similar cities. The findings point to a significant opportunity to leverage geoethnographic methods in order to focus on resident perceptions and preferences to improve food access.

* Alex B. Hill, MA, PhD student, Anthropology; Project Director, Detroit Food Map Initiative; Wayne State University, Detroit, MI USA; alexbhill@wayne.edu

\section{Author Note}

Alex completed this research as part of his master's thesis work in the Anthropology Program at Wayne State University (WSU). He is now a Ph.D. student in the Anthropology Program at WSU and a researcher with the Urban Health Research Group at the Center for Urban Studies, where he also serves as project director of the Detroit Food Map Initiative.
\end{abstract}




\section{Introduction}

"If we get bad service, we just get mad and don't complain. We must challenge the establishments in our community to step up they game. Treat everybody right!”

$$
\text { - African-American, Male, 56, Focus Group August 22, } 2014
$$

This resident's emphatic response at a focus group encompasses a common theme across all of the study events conducted during the summer of 2014 in Detroit to better understand residents' own perceived access to food. A wide range of misconceptions about food access in Detroit exist, but, most egregiously, food access research in Detroit nearly never asks people what they think of their own access to food.

Among the food access misconceptions in Detroit are that food is purchased primarily at liquor stores (Hansen, 2008) and corner stores or "fringe" food outlets that are found more frequently in neighborhoods and are geographically closer to residential homes than other types of food outlets (Gallagher, 2007). Both the mass media and academia have engaged in piecemeal discussions around food access in Detroit, which has perpetuated myths and likely slowed improvements to food access in the city (Hill, 2017). Detroit is assumed to be a "food desert" despite contradicting evidence of fresh produce being available at grocery stores (Hill \& Naar-King, 2014; LeDoux \& Vojnovic, 2013). In addition, there is a strong dislike for the "food desert" term among Detroit's food advocates (Hill, 2017).

In the United States, areas of imbalanced food access are predominantly low-income and AfricanAmerican, where high rates of obesity, diabetes, and hypertension are confounding (Bodor et al., 2013; Cheadle et al., 1991; Inagami et al., 2006; Izumi et al., 2011; Liu et al., 2007; Zenk et al. 2005). In analyzing food access, most researchers rely on quantitative (price, distance, density) and supply-side valuation metrics. This approach often leads to overly prescriptive understandings of access in food environments and has allowed the "food desert" term to be wantonly applied (Hill, 2017). These limited analyses of food access paint an inaccurate picture in urban centers, specifically Detroit. There is more to food access than delineated "food desert" zones, the number of grocery stores in a city, or how far away they might be from groups of residents.

\section{Background}

In the seminal 2009 U.S. Department of Agriculture (USDA) report on "food deserts," a key recommendation was to explore "how people fit grocery and food shopping into their daily activities and travel patterns, how these activities and patterns expose people to food environments outside of their neighborhoods, and how this may affect their shopping and diet" (Ver Ploeg et al., 2009, p. 48). The USDA has published subsequent reports on food access with less focus on "food deserts" and more emphasis on neighborhood characteristics that support healthy food access (Rhone et al., 2019).

A number of food access studies point toward the need for more research on the lived experiences of people in "food deserts" through multidimensional approaches that combine quantitative and qualitative approaches (Alkon et al., 2013; LeDoux \& Vojnovic, 2013; Shannon, 2014, 2016; Walker et al., 2010). Only a handful of studies in Detroit have actively asked people about their own preferences in accessing food (Budzynska et al., 2013; Coleman et al., 2011; Rose et al., 2010). Public health and geographic approaches broadly ignore "foodways," or the cultural and social practices that affect food provisioning, how and where people purchase food, and what motivates their food access preferences (Alkon et al., 2013). In other contexts, these have been described as "foodscapes," or the social, relational, and political construction of food provisioning and power structures (Miewald \& McCann, 2014).

Food retail environments must be recognized as racialized spaces. Reintroducing ethnographic 
methods to examine spaces of food access is critical, but any effort would be misplaced without a significant examination of the experience of "shopping while Black" (Pittman, 2017). In cities like Detroit, food retailers most often do not reflect the racial and/or ethnic make-up of the community (Pothukuchi, 2016), and the racial discrimination interwoven into the consumer experience is increasingly well documented (Kamaloni, 2019; Pittman, 2017; Reese, 2019). Pittman (2017) and Reese (2019) have documented the change in consumer preferences and attitudes based on racist and discriminatory treatment of consumers in stores.

This study examined the role of foodways in Detroit residents' perceptions of food access and food provisioning choices. The study sought to re-center Detroit residents' experiences in an analysis of food access by introducing a more anthropological, cultural, or "geo-ethnographic" examination of food access in Detroit (Biffle \& Thompson, 2006).

\section{Re-centering Lived Experiences}

This study conducted seven focus groups, one for each city council district in Detroit, and 56 individual interviews with residents of those districts. Both types of study activities were conducted using a 16question guide that included open-ended questions like, "what do you like about food in your community?" as well as specific questions like, "have you had an interaction with a store owner?" The study was supported by the Detroit Economic Growth Corporation (DEGC) and the Detroit Food Justice Task Force (DFJTF), with additional assistance provided by the Detroit Food Policy Council (DFPC) and the Detroit Food Politics Research Group at Wayne State University's Anthropology Department.

The unlikely coalition of supporters from economic development, food justice, academia, and community members allowed for an analysis of the social, political, and economic impacts of food access in Detroit. Members of DEGC and DFJTF sat down in the same room to formulate and agree on a list of questions. DFPC and members of the Wayne State University's Anthropology Department worked together to take notes and record resident feedback. Members from all of the groups gave feedback on the final report. This study was conducted as a baseline for the Detroit Food Policy Council's grocery store engagement work and led to the creation of the Detroit Grocery Coalition's Great Grocer Project.

By engaging residents in focus groups and interviews rather than using only written surveys, this study was able to better understand how Detroit residents utilize the foodways defined by their social networks and social capital when making decisions about how and where to access food. The final study sample included 207 residents. The majority of residents utilized a range of sites and sources each month for their food provisioning. Many residents had (1) extensive knowledge of healthy eating habits, (2) employed multiple strategies for food provisioning that included locations well beyond their neighborhood, and (3) placed high value on in-store treatment and customer service as well as on food prices.

Residents identified a wide range of food access points, from home gardens and fishing to specialty meat markets and distant big-box stores. The foodways identified in this study were articulated by individuals exerting their own choices based on word of mouth in social networks consisting of extended families, neighbors, and church congregations. The prominence of mentions of in-store treatment, discrimination, and customer service remind researchers that grocery shopping is a social activity and not one simply defined by the closest store location, lowest prices, or the presence of the most healthful foods.

"I was treated very poorly in one of our [Detroit] neighborhood stores and it was the end of the week. Now I'm the pastor, so as you can imagine my weekend sermon included a story of my treatment at that store. Afterwards, members of my congregation came up and shared their own stories of mistreatment at the same store. We can make a movement and really put pressure on these stores." - D5 
"I won't go to the corner [to shop at the neighborhood store]. I rely on my neighbor to drive me to the store [a chain supermarket outside the city]. We get together once a month, talk about the deals and get started." - D7

"Family all shops together, we don't live together, but we gotta make ends meet so we pool our EBT and split up where everyone goes so we can stretch [our budgets]." - D4

"He [grocery store owner] spit over the window. There is extreme lack of respect. My niece and her family decided that they will never shop from that place. We told everyone not to." - D6

Some residents had stronger social ties than others, where they could exert greater influence on community foodways. Residents highlighted in-store treatment as an important factor for food provisioning, whether in their neighborhood or visiting a chain supermarket in the suburbs. In-store treatment was most often referred to as "customer service" and focused on negative interactions with store owners and employees, combined with a perception that local grocery stores were not receptive to criticism. Generalizations cannot be made of all stores in any given geographic area, as positive and negative experiences occurred both inside and outside the city. In one very telling instance, an 11-story high-rise apartment building for low-income senior citizens sat directly adjacent to a full-line grocery store, but the residents said they preferred to cross the street to shop for food at the CVS pharmacy and store because they were treated better there than at the grocery store.

"If we get bad service, we just get mad and don't complain. We must challenge the establishments in our community to step up the game. Treat everybody right!" - D5

"It's more difficult to get to a grocery store in the suburbs, the location is often less convenient, but the customer service is responsive." - D4

"There are higher income level people that shop there, and it is supposed to be high-end, but the food is still not as good as in Kroger. But I'm treated better [at Harbortown]." - D5

Occasionally, residents noted that their experience was so bad that they were glad when a nearby grocery store closed, or they persuaded their friends and family not to shop at a particular store any longer.

"Once my nephew purchased a cereal from a store where I regularly shop. Later when he came home, he found that it was expired ... He told me about the situation ... and then we both went back to the store, the manager of that store didn't take it back; he said he doesn't sell expired products. . . That I was the last time I set foot in that store." - D5

"The storeowners disrespected us.... They used to talk horribly to the women and children.... I'm so glad that they left from here. People used to get sick from the food purchased from that store.. . . Most of the items in that store were expired ... for example you could see that the cheese was molded ... and chicken which was returned as it was bad, was placed back in the freezer so it could be sold to the next customer." - D6

"Store owners shouldn't treat all customers bad just because of one bad experience." - D3 
This same theme has been covered in the local news media about Detroit, typically focused on store cleanliness and below-average options in specific neighborhoods. As quoted in Smith and Hurst (2007), a resident named Gordon A. said, "Some stores claim to be serving a 'black clientele,' but it's just an excuse for stocking bad quality goods."

The topic of race and privilege has only recently entered the research around food provisioning and grocery stores in the metro Detroit area. One study found that in-store treatment became worse for each mile that a resident traveled outside their neighborhood for a $7 \%$ increase in the odds of "unfair" treatment (Zenk et al., 2014). Focus-group participants noted similar themes:

“... Because this is a black neighborhood, everyone gives us the secondary treatment." - D6

However, negative in-store treatment was mentioned to have occurred in neighborhood stores and suburban stores alike. One participant, a local pastor, noted,

"Most of the time I'm treated very well in local stores, but not in suburban stores [Grosse Pointe]." - D5

Residents were able to identify specific stores in their own neighborhoods as well as the suburbs that they preferred based on the way they felt treated in particular stores. Sometimes these preferences were based on lived experience, and other times the preference was based on anecdotal experience shared by family, friends, or neighbors.

\section{Discussion}

These new findings provide direction for future work that needs to act on the feedback and lived experiences of residents accessing food. The findings help to highlight a number of themes that demonstrate the foodways of Detroiters. The fact that neither nutrition knowledge nor geographic location was a barrier for those who participated in study events negates assumptions that Detroiters do not know how to eat healthy or that they only shop at nearby liquor stores.

The multiple strategies for food provisioning broke down along lines of social cohesion. Participants from the same groups would share information on food item sales or upcoming deals. Finally, the common theme of in-store treatment and discrimination was a thread that was carried from participant to participant and community to community. Participants made phone calls and conversed during and after church services to define their own foodways based on how they had recently been treated within particular food stores. These findings mirror the work of Reese (2019) and Pittman (2017), who found that racialized food spaces drove residents to create alternative pathways to food.

Similar to alternative pathways to food, the type of group that hosted a focus group may have influenced participant responses. It is likely that the social capital of a particular community group or congregation that hosted a study event could serve as an indicator for the level of participation by nearby residents or members. Church-based groups that hosted a focus group had the strongest attendance as well as relationships among participants. One long-standing community organization rivaled the churchbased groups, but those participants noted they were self-organized from two different church congregations. The church-based groups were also more likely to host healthy cooking programs, diabetes education, and similar programming, which served to build a shared base of knowledge among participants. 


\section{Conclusion}

Foodways follow a social process rather than one defined by a specific bounded geography. Food access studies regularly examine the food environment but might be better focused on "food ecology" or foodways that include the social, political, and economic relations within the food environment. Similar to Pittman's (2017) work, this study was able to identify social and cultural strategies utilized to mitigate and avoid discrimination in food retail experiences.

The findings highlight the importance of understanding foodways and individual choice among populations living in an assumed "food desert." The creative and socio-cultural strategies used for food provisioning described at all of the study events demonstrate the critical need for food access research to more regularly pair ethnographic methods with quantitative exercises in determining the skills, needs, and desires of communities facing food insecurity. Reversing misperceptions is of the utmost importance if food access efforts hope to break down assumptions and support effective community solutions.

Future research should work to engage residents in geo-ethnographic methods to understand foodways. In addition, food retailers were described as the key drivers of foodway adaptations in Detroit, and there must be a more systematic method used to understand retailer perspectives. Researchers may be a helpful conduit to facilitate connections between food retailers and community groups, but should place the community in the lead. These combined strategies of engaging residents in geo-ethnographic foodway explorations and exploring food retailers' perspectives offer a unique opportunity to advance community food access without simply relying on quantitative measures and overlooking communities' food provisioning preferences.

\section{References}

Alkon, A. H., Block, D., Moore, K., Gillis, C., DiNuccio, N., \& Chavez, N. (2013). Foodways of the urban poor. Geoforum, 48, 126-135. https://doi.org/10.1016/i.geoforum.2013.04.021

Biffle, R. L., \& Thompson, P. B. (2006). Geo-ethnography, An interdisciplinary method for exploring schools, communities and cultures [Book review]. The International Journal of Diversity in Organizations, Communities, and Nations: Annual Review, 6(3), 75-82. https://doi.org/10.18848/1447-9532/CGP/v06i03/39183

Bodor, J. N., Hutchinson, P. L., \& Rose, D. (2013). Car ownership and the association between fruit and vegetable availability and diet. Preventive Medicine, 57(6), 903-905. https://doi.org/10.1016/j.ypmed.2013.10.003

Budzynska, K., West, P., Savoy-Moore, R. T., Lindsey, D., Winter, M., \& Newby, P. K. (2013). A food desert in Detroit: Associations with food shopping and eating behaviours, dietary intakes and obesity. Public Health Nutrition, 16(12), 2114-2123. https://doi.org/10.1017/S1368980013000967

Cheadle, A., Psaty, B. M., Curry, S., Wagner, E., Diehr, P., Koepsell, T., \& Kristal, A. (1991). Community-level comparisons between the grocery store environment and individual dietary practices. Preventive Medicine, 20(2), 250-261. https://doi.org/10.1016/0091-7435(91)90024-X

Coleman, M., Weatherspoon, D. D., Weatherspoon, L., \& Oehmke, J. F. (2011). Food retailing in an urban food desert: Strategies for success in fresh fruits and vegetables. Available at SSRN. https://doi.org/10.2139/ssrn.1788583

Gallagher, M. (2007). Examining the impact of food deserts on public health in Detroit. Mari Gallagher Research \& Consulting Group. https://www.marigallagher.com/2007/06/19/examining-the-impact-of-food-deserts-on-public-health-indetroit-june-19-2007/

Hansen, C. (2010, April 20). America now: City of heartbreak and hope. Dateline NBC. http://www.nbcnews.com/id/36665950/ns/dateline nbc-the hansen files with chris hansen/t/america-nowcity-heartbreak-hope/\#.UwEXuF6Lga4

Hill, A. B. (2017). Critical inquiry into Detroit's “food desert" metaphor. Food and Foodways, 25(3), 228-246. https://doi.org/10.1080/07409710.2017.1348112 
Hill, A. B., \& Naar-King, S. (2014). Fruit and vegetable availability, quality, \& consumption in Detroit's food desert among African American adolescents with obesity. Food and Nutrition, 14-19. https://apha.confex.com/apha/142am/webprogram/Paper307451.html

Inagami, S., Cohen, D. A., Finch, B. K., \& Asch, S. M. (2006). You are where you shop: Grocery store locations, weight, and neighborhoods. American Journal of Preventive Medicine, 31(1), 10-17. https://doi.org/10.1016/j.amepre.2006.03.019

Izumi, B. T., Zenk, S. N., Schulz, A. J., Mentz, G. B., \& Wilson, C. (2011). Associations between neighborhood availability and individual consumption of dark-green and orange vegetables among ethnically diverse adults in Detroit. Journal of the American Dietetic Association, 111(2), 274-279. https://doi.org/10.1016/j.jada.2010.10.044

Kamaloni, S. (2019). What do you have there? Carrying race in my shopping basket. In Understanding Racism in a PostRacial World (pp. 161-191). Palgrave Macmillan. https://doi.org/10.1007/978-3-030-10985-1 6

LeDoux, T. F., \& Vojnovic, I. (2013). Going outside the neighborhood: The shopping patterns and adaptations of disadvantaged consumers living in the lower eastside neighborhoods of Detroit, Michigan. Health \& Place, 19, 1-14. https://doi.org/10.1016/j.healthplace.2012.09.010

Liu, G. C., Wilson, J. S., Qi, R., \& Ying, J. (2007). Green neighborhoods, food retail and childhood overweight: Differences by population density. American Journal of Health Promotion, 21(Suppl. 4), 317-325. https://doi.org/10.4278/0890-1171-21.4s.317

Miewald, C., \& McCann, E. (2014). Foodscapes and the geographies of poverty: Sustenance, strategy, and politics in an urban neighborhood. Antipode, 46(2), 537-556. https://doi.org/10.1111/anti.12057

Morland, K., Roux, A. V. D., \& Wing, S. (2006). Supermarkets, other food stores, and obesity: The atherosclerosis risk in communities study. American Journal of Preventive Medicine, 30(4), 333-339. https://doi.org/10.1016/j.amepre.2005.11.003

Pittman, C. (2020). "Shopping while Black": Black consumers' management of racial stigma and racial profiling in retail settings. Journal of Consumer Culture, 20(1), 3-22. https://doi.org/10.1177/1469540517717777

Pothukuchi, K. (2016). Bringing fresh produce to corner stores in declining neighborhoods: Reflections from Detroit FRESH. Journal of Agriculture, Food Systems, and Community Development, 7(1), 113-134. https://doi.org/10.5304/jafscd.2016.071.013

Reese, A. M. (2019). Black food geographies: Race, self-reliance, and food access in W ashington. UNC Press Books. https://doi.org/10.5149/northcarolina/9781469651507.001.0001

Rhone, A., Ver Ploeg, M., Williams, R., \& Breneman, V. (2019). Understanding low-income and low-access census tracts across the nation: Subnational and subpopulation estimates of access to bealthy food (Economic Information Bulletin No. 209). U.S. Department of Agriculture, Economic Research Service. https://ageconsearch.umn.edu/record/289136/files/EIB-209.pdf

Rose, D., Bodor, J. N., Hutchinson, P. L., \& Swalm, C. M. (2010). The importance of a multi-dimensional approach for studying the links between food access and consumption. The Journal of Nutrition, 140(6), 1170-1174. https://doi.org/10.3945/jn.109.113159

Shannon, J. (2014). Food deserts: Governing obesity in the neoliberal city. Progress in Human Geography, 38(2), $248-266$. https://doi.org/10.1177/0309132513484378

Shannon, J. (2016). Beyond the supermarket solution: Linking food deserts, neighborhood context, and everyday mobility. Annals of the American Association of Geographers, 106(1), 186-202. https://doi.org/10.1080/00045608.2015.1095059

Smith, J., \& Hurst, T. (2007, July 26). Grocery closings hit Detroit hard: City shoppers' choices dwindle as last big chain leaves. Detroit News. 
Ver Ploeg, M., Breneman, V., Farrigan, T., Hamrick, K., Hopkins, D., Kaufman, P., Lin, B.-H., Nord, M., Smith, T. A., Williams, R., Kinnison, K., Olander, C., Singh, A., \& Tuckermanty, E. (2009). Access to affordable and nutritious food: Measuring and understanding food deserts and their consequences: Report to congress (Administrative Publication No. AP-036). U.S. Department of Agriculture, Economic Research Service. https://www.ers.usda.gov/publications/pub-details/?pubid=42729

Walker, R. E., Keane, C. R., \& Burke, J. G. (2010). Disparities and access to healthy food in the United States: A review of food deserts literature. Health \& Place, 16(5), 876-884. https://doi.org/10.1016/i.healthplace.2010.04.013

Zenk, S. N., Schulz, A. J., Israel, B. A., Mentz, G., Miranda, P. Y., Opperman, A., \& Odoms-Young, A. M. (2014). Food shopping behaviours and exposure to discrimination. Public Health Nutrition, 17(5), 1167-1176. https://doi.org/10.1017/S136898001300075X

Zenk, S. N., Schulz, A. J., Israel, B. A., James, S. A., Bao, S., \& Wilson, M. L. (2005). Neighborhood racial composition, neighborhood poverty, and the spatial accessibility of supermarkets in metropolitan Detroit. American Journal of Public Health, 95(4), 660-667. https://doi.org/10.2105/AJPH.2004.042150 